\title{
Basal and Frontal Accretion Processes versus BSR Characteristics along the Chilean Margin
}

\author{
I. Vargas-Cordero, ${ }^{1}$ U. Tinivella, ${ }^{2}$ F. Accaino, ${ }^{2}$ F. Fanucci, ${ }^{3}$ M. F. Loreto, ${ }^{2}$ M. E. Lascano, ${ }^{4}$ \\ and C. Reichert ${ }^{5}$
}

\author{
${ }^{1}$ Barcelona Center for Subsurface Imaging, Instituto de Ciencias del Mar, CSIC, Passeig Marítim de la Barceloneta 37-49, \\ 08003 Barcelona, Spain \\ ${ }^{2}$ Istituto Nazionale di Oceanografia e di Geofisica Sperimentale (OGS), Borgo Grotta 42C, Trieste, 34010 Sgonico, Italy \\ ${ }^{3}$ Dipartimento di Scienze Geologiche, Ambientale e Marine, Università degli Studi di Trieste, C. San Giovanni, \\ Via E. Weiss 2, 34127 Trieste, Italy \\ ${ }^{4}$ International Centre for Theoretical Physics (ICTP), Strada Costiera 11, 34014 Trieste, Italy \\ ${ }^{5}$ Federal Institute for Geosciences and Natural Resources (BGR), Stilleweg 2, 30655 Hannover, Germany
}

Correspondence should be addressed to I. Vargas-Cordero, ivargas@ub.edu

Received 1 December 2010; Accepted 13 July 2011

Academic Editor: Ingo Pecher

Copyright ( $) 2011$ I. Vargas-Cordero et al. This is an open access article distributed under the Creative Commons Attribution License, which permits unrestricted use, distribution, and reproduction in any medium, provided the original work is properly cited.

\begin{abstract}
Multichannel seismic reflection data recorded between Itata $\left(36^{\circ} \mathrm{S}\right)$ and Coyhaique offshores $\left(43^{\circ} \mathrm{S}\right)$ were processed to obtain seismic images. Analysis of the seismic profiles revealed that weak and discontinuous bottom simulating reflectors were associated to basal accretion processes, while strong and continuous bottom simulating reflectors were associated to frontal accretion processes. This can be explained considering that during basal accretion processes, extensional tectonic movements due to uplifting can favour fluid escapes giving origin to weaker and most discontinuous bottom simulating reflectors. During frontal accretion processes (folding and thrusting), high fluid circulation and stable tectonic conditions however can be responsible of stronger and most continuous bottom simulating reflectors. Along the Arauco-Valdivia offshores, steep accretionary prisms, normal faults, slope basins, and thicker underplated sediment bed were associated to basal accretion, while along the Itata, Chiloe and Coyhaique offshores, small accretionary prisms, folding, and thinner underplated sediment bed were associated to frontal accretion.
\end{abstract}

\section{Introduction}

In marine seismic records, the Bottom Simulating Reflector (BSR) is a good indicator of gas hydrate presence. The BSR has allowed defining the distribution of gas hydrate [1-4] along several continental margins. The BSR is associated with the acoustic interface between overlying sediment containing gas hydrate, which increases compressional seismic velocity, and underlying sediment containing free gas, which decreases compressional seismic velocity $[2,5]$. The BSR has been identified in seismic sections in accretionary complexes along both convergent and passive margin settings [1]. Along the Chilean continental margin, the BSR is well reported by several geophysical cruises. In particular, the BSR is recognized along the accretionary prism [6-11].
Along the Chilean margin, two main tectonic processes are recognized. The first one is associated with frontal accretion and the second one with basal accretion [11-14].

This study is aimed at identifying the main morphostructures on the continental margin, in particular on oceanic trench and continental slope. In this way, by interpreting six stacked and poststack time-migrated sections, relationships between BSR characteristics and tectonic processes can be identified (Figure 1).

\section{Tectonic and Geological Setting}

The study area is located along the Central Chile, between $35^{\circ}$ and $45^{\circ} \mathrm{S}$ including Itata, Arauco, Toltén, and Valdivia 




offshores (from $36^{\circ}$ to $40^{\circ} \mathrm{S}$ ) and Chiloé and Coyhaique offshores (from $43^{\circ}$ to $45^{\circ} \mathrm{S}$ ) (Figure 1 ).

The central and south Chile $\left(34^{\circ}-46^{\circ} \mathrm{S}\right)$ is limited northwards the Juan Fernandez ridge and southwards the Chile rise. The Juan Fernandez ridge is characterized by Pampean flat-slab segment, which presents a lack of volcanism and foreland uplift (Sierras Pampeanas) the highest mountains of the Andes, such as the Aconcagua massif (6989 m). South of Pampean flat-slab segment, the Andean margin is characterized by normal subduction (dips $30^{\circ}$ ) extending from $34^{\circ}$ to $46^{\circ} \mathrm{S}$ up to the Chile triple junction. The convergence between the Nazca and South American plates occurs at an average rate of $6.4 \mathrm{~cm} / \mathrm{yr}$ [15]. In this area (from $34^{\circ}$ to $45^{\circ} \mathrm{S}$ ) the entire margin is characterized by an oblique 
vector of convergence $\left(\mathrm{N} 78^{\circ} \mathrm{E}\right)$ and reaches an orthogonal direction in the austral segment.

The continental slope consists of a lower and an upper slope. The lower slope is associated with the accretionary prism that is built by turbidites that are incorporated from trench fill to the lower slope as accreted sediments $[12,16]$, while the upper slope is associated with an important volume of terrigenous sediments from Andean arc volcanic rocks [17], deposited onto a continental metamorphic basement [18].

The oceanic trench is filled by sediments of partly more than $2 \mathrm{~km}$ thickness locally appearing rather as a flat plain than as a bathymetric depression [12]. The trench infill is composed of interbedded turbiditic and hemipelagic strata, which show certain cyclicity in their seismic reflection pattern that is interpreted as the influence of global climate cycles on sedimentation [16, 19]. The oceanic basement represents the Nazca Plate subducting beneath the SouthAmerica Plate and is constituted by pelagic sediments and oceanic basalts.

\section{Data and Seismic Processing}

In this study six seismic lines are analyzed. Four of them (SO161-44, SO161-35, SO161-29, and SO161-40; see Figure 1) were acquired by the RV SONNE cruise (JanuaryFebruary 2001) as part of the project "Subduction Processes Off Chile (SPOC)," and the other two (RC2901-728 and RC2901-734; see Figure 1) were acquired by RV CONRAD cruise (January-February 1988), as part of the project "MidOcean Spreading Ridge (Chile Ridge)" of the Ocean Drilling Program (ODP). Prestack seismic data of four seismic lines (RC2901-728, SO161-44, SO161-29, and RC2901-734) were used, while only the stacked seismic data are available for the other two lines (SO161-35 and SO161-40). Seismic data were acquired during the RV SONNE cruise using a $3000 \mathrm{~m}$ long 132-channel digital streamer with $12.5 \mathrm{~m}$ between the first 24 channels and $25 \mathrm{~m}$ between the other channels. The seismic source was a tuned array of 20 air guns, providing a total volume of $54.1 \mathrm{l}$, with a shot spacing of $50 \mathrm{~m}$. Seismic data acquired during RV CONRAD cruise used a $3000 \mathrm{~m}$ long digital streamer, with 240 channels and intertrace of $12.5 \mathrm{~m}$. The seismic source was a tuned array of 10 air guns with a total volume of 61.31 , with a shot spacing of $50 \mathrm{~m}$.

The seismic processing was performed by using the open source Seismic Unix (SU) software [20]. In order to obtain an accurate seismic image, a standard processing [21] was performed on the Prestack seismic data followed by the poststack time migration (Phase Shift and Stolt methods). In order to evaluate the seismic attributes of the stacked section, a true-amplitude processing was performed. In fact, in each processing step, the preservation of the amplitude spectrum was checked. In the case of SO161-35 and SO161-40 seismic lines, for which only stacked seismic data were available, a phase shift migration by using the water seismic velocity $(1480 \mathrm{~m} / \mathrm{s})$ was performed.

The first step of the standard processing was to convert the data from SEGY to SU format. Once converted in SU format, a checking of the minimum offset was done by using the first arrival (direct wave). In fact, assuming the seismic water velocity equal to $1480 \mathrm{~m} / \mathrm{s}$ (from direct wave analysis), a time shift of $0.12 \mathrm{~s}$ was identified in the SO161-44 seismic line. It was corrected shifting in $0.12 \mathrm{~s}$ all seismic data.

The next step was to define the geometrical arrangement of the prestack data. In this study, the source-receiver coordinates were defined arbitrarily without considering the geographic coordinates, and the offset and common midpoint (CMP) were calculated by using the source-receiver coordinates previously calculated. In the case of the SO16144 and SO161-29 seismic lines, two different streamers were considered: the first one of 24 channels spaced every $12.5 \mathrm{~m}$ and the second one of 108 channels spaced every $25 \mathrm{~m}$. The setting geometry was assigned separately and, then, integrated as a single streamer. CMP distances of $6.25 \mathrm{~m}$ (for RC2901-728 and RC2901-734 seismic lines) and $12.5 \mathrm{~m}$ (for SO161-44 and SO161-29 seismic lines) were defined.

To attenuate noise and correct the effects on amplitude due to wavefront spherical divergence, a band-pass filter (15$70 \mathrm{~Hz}$ ) and a gain were applied, respectively.

In the SO161-44 seismic line, strong noises associated with out-of-plane reflections (sideswipe), probably due to the irregular morphology, were recognized. In order to attenuate this noise, a dip filter (slope ranging $8-5.510^{-4}$ ) in the F-K domain was applied.

A stacking velocity analysis every 100 CMP (i.e., every $1250 \mathrm{~m}$ for the SO161-44 and SO161-29 seismic lines and every $625 \mathrm{~m}$ for the RC2901-728 and RC2901-734 seismic lines) was performed. Consequently, stacking velocity models were used to perform the stacking [21]. In order to obtain an accurate seismic image, a poststack time migration was performed; thus, the stacking velocity models were converted into interval velocity models. Moreover, different tests of poststack time migration (Stolt and phase shift methods) were performed. The best results were obtained by using the phase shift method. Finally, to obtain the final poststack-migrated sections, a band-pass filter $(15-70 \mathrm{~Hz})$, mixing traces, AGC gain ( $800 \mathrm{~ms}$ window), and muting were applied.

\section{Results}

4.1. $R C 2901-728$. RC2901-728 time-migrated section, located offshore Itata $\left(36^{\circ} \mathrm{S}\right)$, is characterized by a regular oceanic basement top, with a small number of structures in the westernmost part, while in depth underthrust structures are evident.

At the base of lower slope, an anticline ramp was recognized. Upslope several thrusts define an imbricated complex (approximately $15 \mathrm{~km}$ width). At about $8 \mathrm{~s}$, highamplitude reflections are interpreted as a decollement surface (Figure 2). Below this level, another reflector with high amplitude can be associated with the oceanic basement top. An uplifted slope basin behind a subvertical is characterized by divergent and continuous reflectors (Figure 2). Downwards and upwards of the slope basin chaotic reflections with low instantaneous amplitude (see insert in the Figure 2) can be related to slump deposits (CDPs 8000 and 9500, resp.).). From CDPs 8000 to 13000 , a strong and continuous BSR 


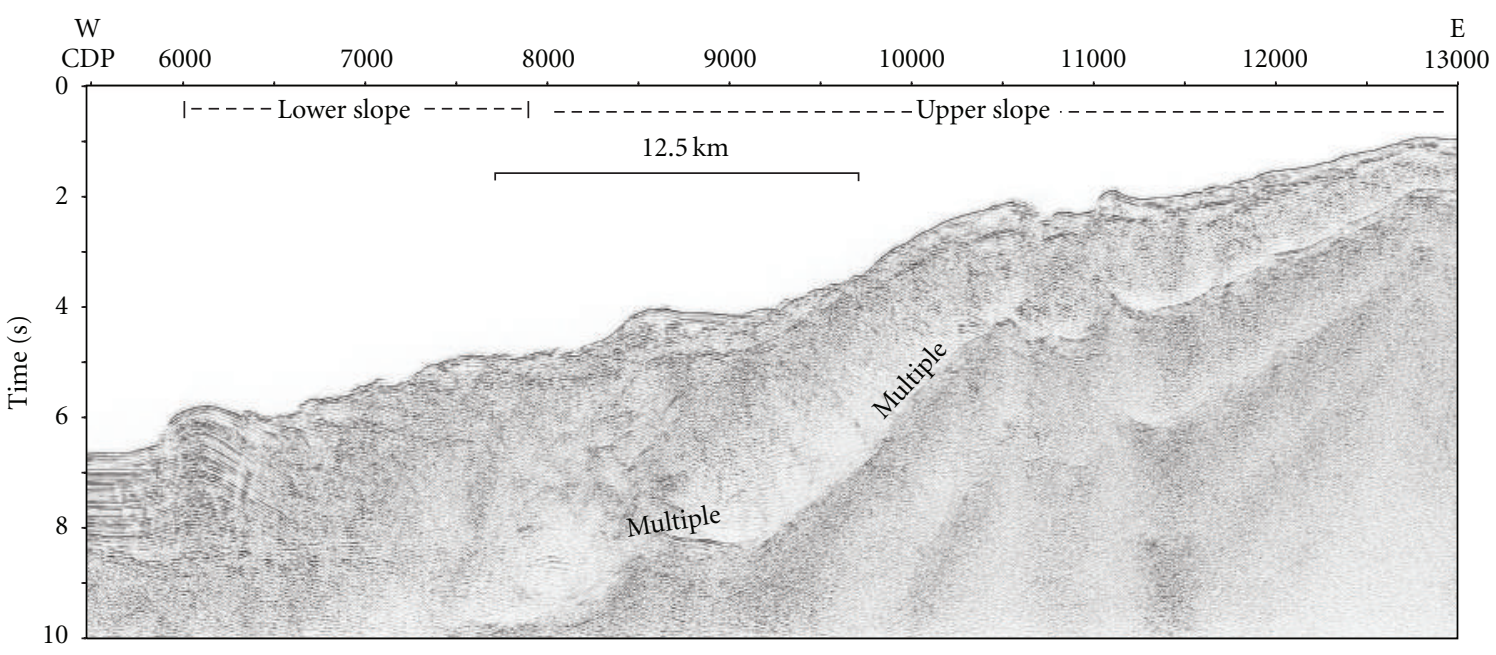

(a)

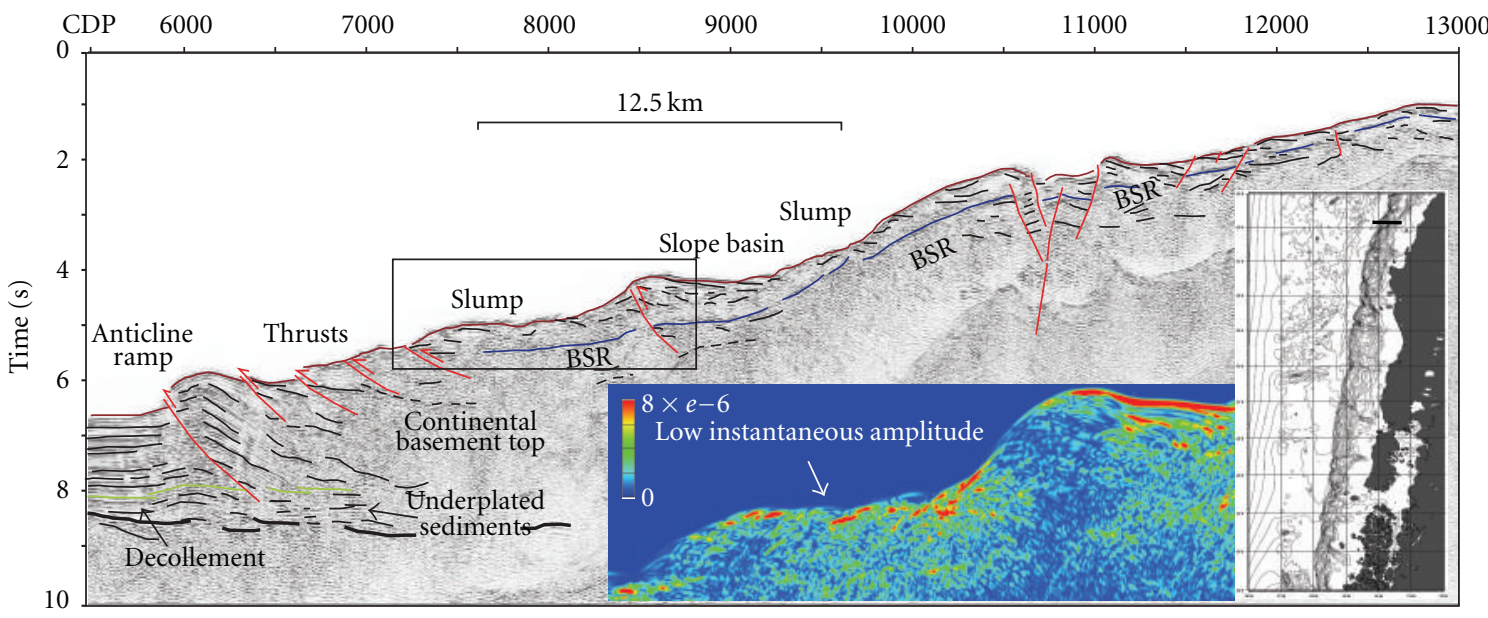

(b)

Figure 2: RC2901-728 seismic profile. Poststack time-migrated (a) and poststack time-migrated (b) sections with superimposed line drawing section. The box indicates the location of the instantaneous section reported in the insert.

was identified and can be associated to gas hydrate presence. From CDPs 10500 to 11500 , a negative flower structure was recognized (Figure 2). In depth, reflections with high amplitude were associated to the continental basement top.

4.2. SO161-44. SO161-44 time-migrated section (Figure 3) located offshore Arauco (close to $38^{\circ} \mathrm{S}$ ) shows different features compared to the previous section. Several faults at top of oceanic basement were recognized.

At the base of the slope, slightly deformed reflectors, thrusts, and underthrusts affect the trench fill. The top of an acoustically semitransparent level (about $7 \mathrm{~s}$ ) can be associated with a decollement surface.

The lower slope is wide about $15 \mathrm{~km}$ and is steeper than the section SO161-44. At the base of the lower slope, slightly deformed sediments are recognized, which involve only the shallowest bed of the sedimentary trench fill (about $0.8 \mathrm{~s}$ of thickness; Figure 3). The decollement surface and the oceanic basement top (about $6 \mathrm{~s}$ and $7.5 \mathrm{~s}$ ) show pull-up features (Figure 3). From CDPs 5700 to 6600, a thrust sequence shapes a steep-dipping lower slope. Eastward, a normal fault scarp with offset of about $1 \mathrm{~s}$ (close to CDP 7000) was recognized. Here, chaotic reflections were observed. Note that fault scarp marks the boundary between lower slope and upper slope.

The upper slope shows an irregular topography disrupted by two main thrusts (at CDPs 7000 and 8000). Chaotic reflections, observed in the shallow and deep part, are evident (Figure 3). From CDPs 7200 to 7600 (5 km of width) a depressed zone characterized by morphological highs and a graben structure was imaged. Some slope basins on the top of seaward verging thrusts were recognized. At about $3.2 \mathrm{~s}$, a discontinuous and strong BSR was identified. Reflections with high amplitude at about $4 \mathrm{~s}$ can be interpreted as the continental basement top. 


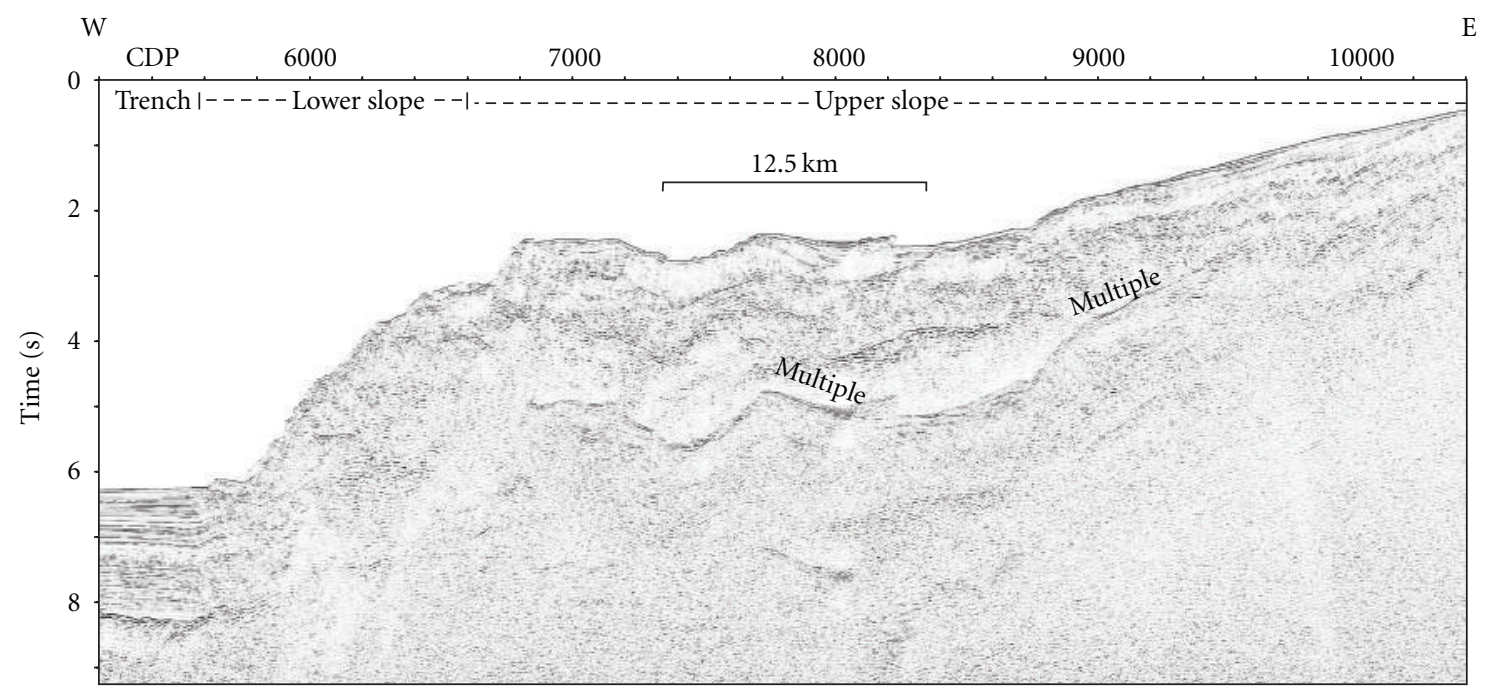

(a)

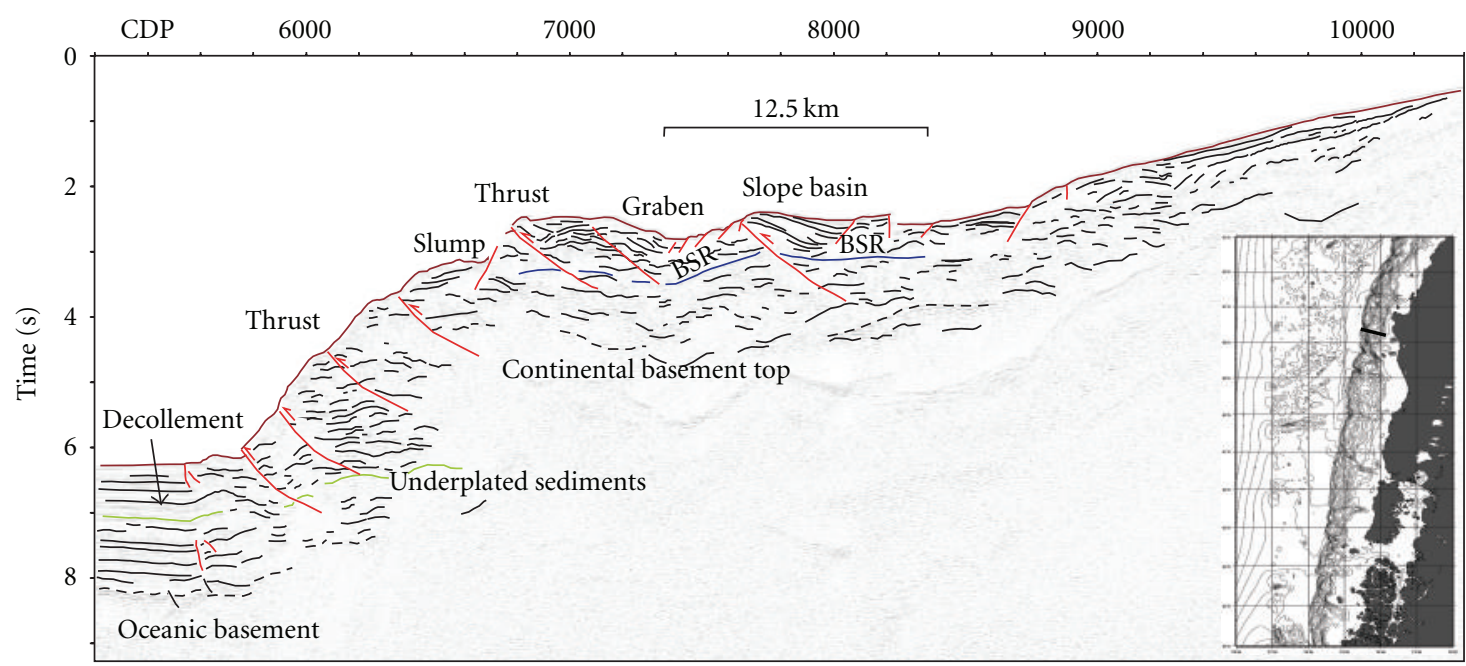

(b)

FIGURE 3: SO161-44 seismic profile. Poststack time-migrated (a) and poststack time-migrated (b) sections with superimposed line drawing section.

4.3. SO161-35. SO161-35 poststack time-migrated section, located south of Mocha Island close to $38.5^{\circ} \mathrm{S}$ shows an irregular oceanic basement top.

The lower slope is characterized by an irregular topography, which is disrupted by a morphological high (about CDP 9000). Downslope a closely spaced thrust section was recognized, while upslope two main widely spaced thrusts shape the accretionary prism (Figure 4). At about $7 \mathrm{~s}$ and $8 \mathrm{~s}$, high-amplitude reflections and pull-up features were associated with the top of the underplated sediment bed and to the oceanic basement top. From CDPs 9200 to 10000 a weak and discontinuous BSR was recognized (Figure 4). The sea bottom is characterized by anomalous morphological highs, which can be associated with possible mud volcanoes. From CDPs 10200 to 11500, two main slope basins were recognized. Note that these basins are affected mainly by the displacement of normal and inverse faults (see Figure 4). On the right side of the basins, normal faults configuring "halfgraben" structures were recognized (Figure 4). At about $5 \mathrm{~s}$, reflections with high amplitude associated with the continental basement top were recognized.

4.4. SO161-40. SO161-40 poststack time-migrated section (Figure 5), located at south of Chiloe island $\left(43.5^{\circ} \mathrm{S}\right)$, is characterized by a regular oceanic basement top. The trench sediments are affected by thrusts and normal faults.

At the base of the lower slope, a thrust structure forms an anticline ramp. In depth, chaotic reflections and inactive faults affect the sedimentary sequence; here, the underplated bed and oceanic basement tops are less clear, but some high-amplitude reflections can be recognized at $6 \mathrm{~s}$ and $7 \mathrm{~s}$, respectively (Figure 5). From CDPs 7800 to 10000, scarps are evident and can be associated to normal faults. In depth, from CDPs 8000 to 9000, a strong and continuous BSR 


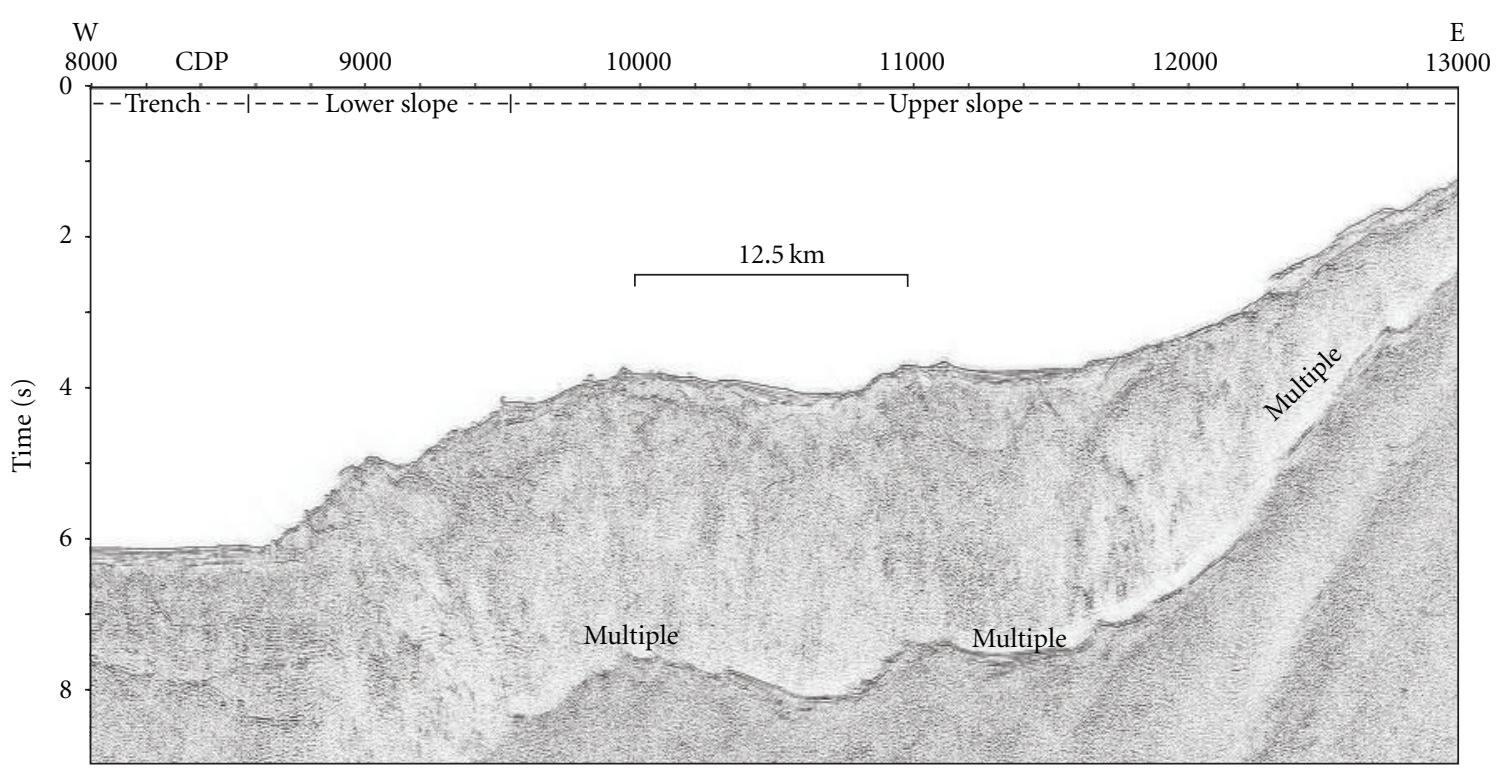

(a)

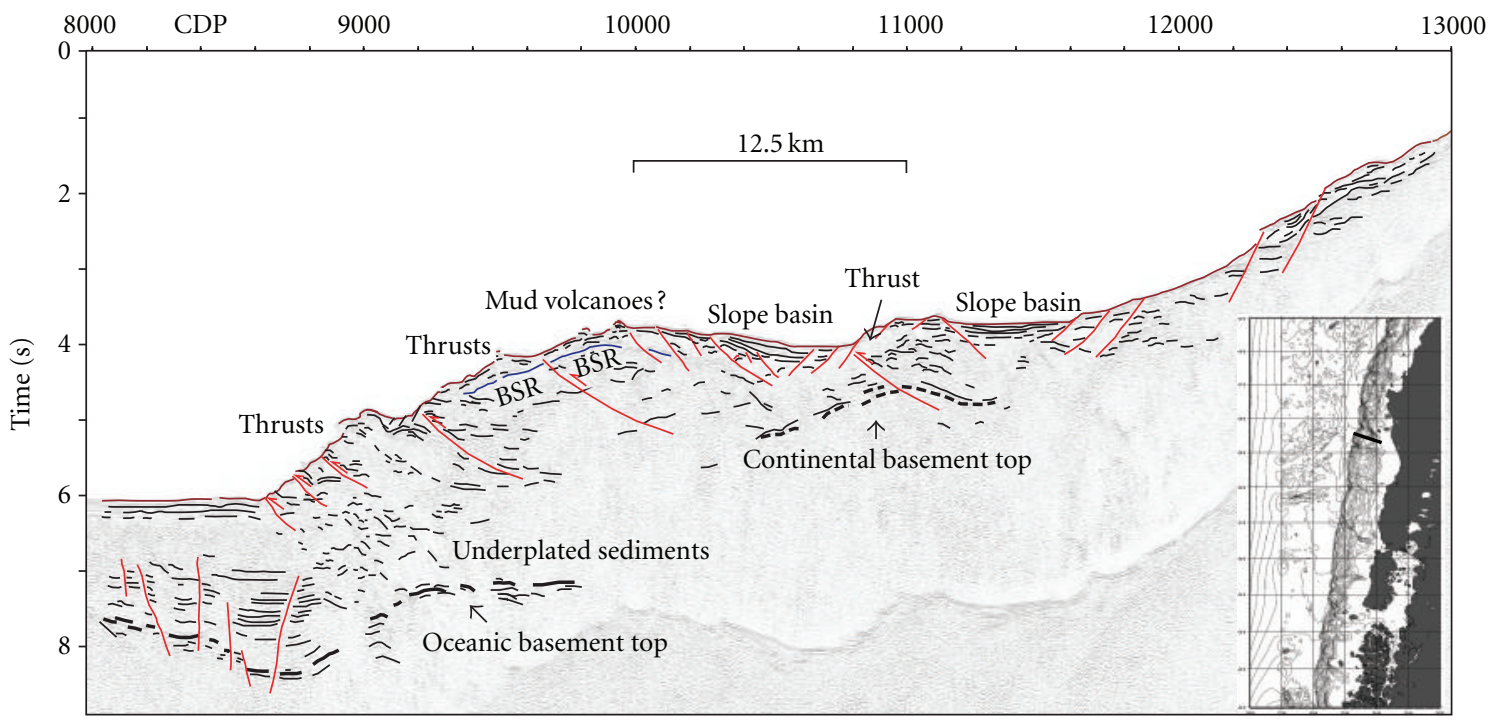

(b)

FIgURE 4: SO161-35 seismic profile. Poststack time-migrated (a) and poststack time-migrated (b) sections with superimposed line drawing section.

was recognized. Note that upslope the BSR is interrupted by active faults that configure a possible flower structure (Figure 5). At about $3 \mathrm{~s}$, high-amplitude reflections, affected by faults, were associated to the continental basement top. Upslope from CDPs 9000 to 10000, a morphological high and a submarine channel ( $3 \mathrm{~km}$ width), controlled by normal faults was recognized (Figure 5).

\section{Discussions and Conclusions}

Two main accretion processes can be recognized along the Chilean margin: the first one is related to frontal accretion and the second one to basal accretion [12]. Both processes, frontal and basal accretions, were recognized in all seismic sections. In particular, areas characterized by regular oceanic basement top, morphological highs, and thrusting across the continental slope (RC2901-728, SO161-40, and RC2901-734; Figure 6) can be associated to frontal accretion, while areas characterized by irregular oceanic basement top, absence of morphological highs, and widen and steep continental slopes can be associated to basal accretion. Moreover, relationships between the thickness of the underplated sediment bed and the morphology of lower slope can be described. Thus, thicker underplated sediment bed contributes to the formation of steeper slopes, while thinner underplated sediment bed contributes to the formation of rougher slopes. In RC2901-728 and SO161-40 sections, a thin underplated sediment bed $(0.5 \mathrm{~s})$ is in agreement with a rougher slope, 


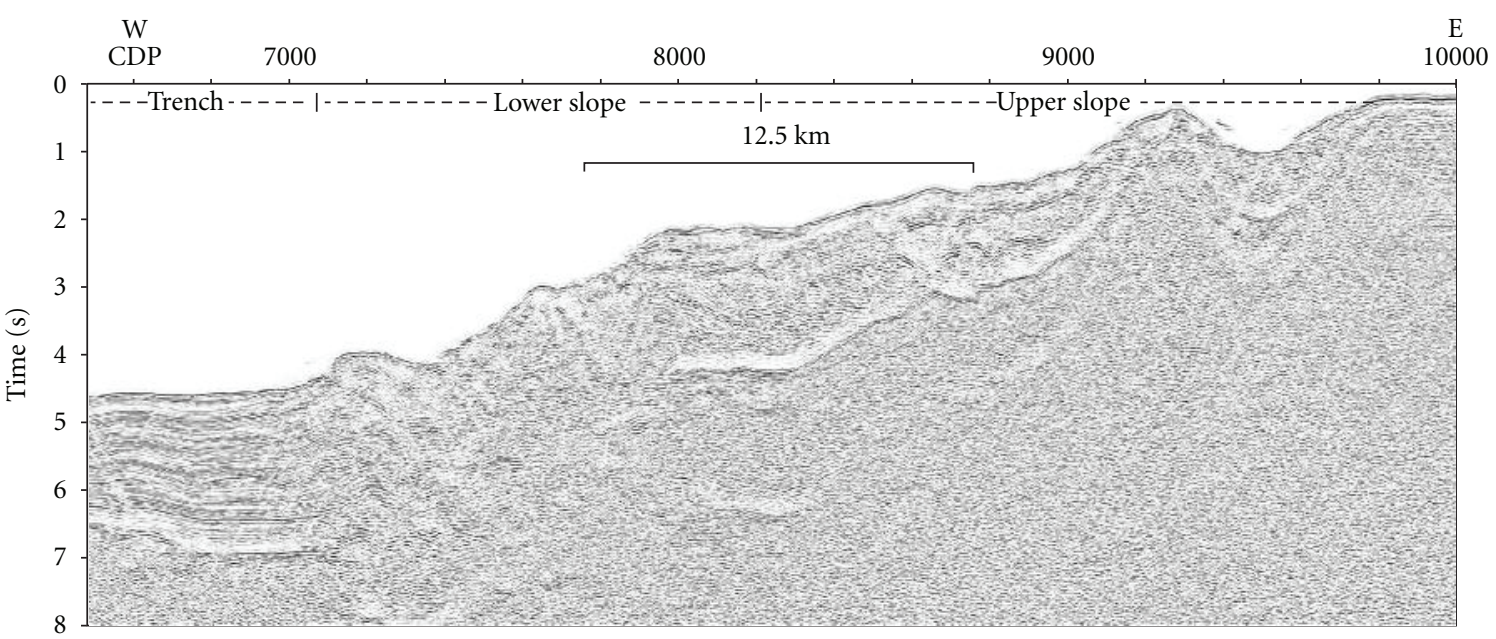

(a)

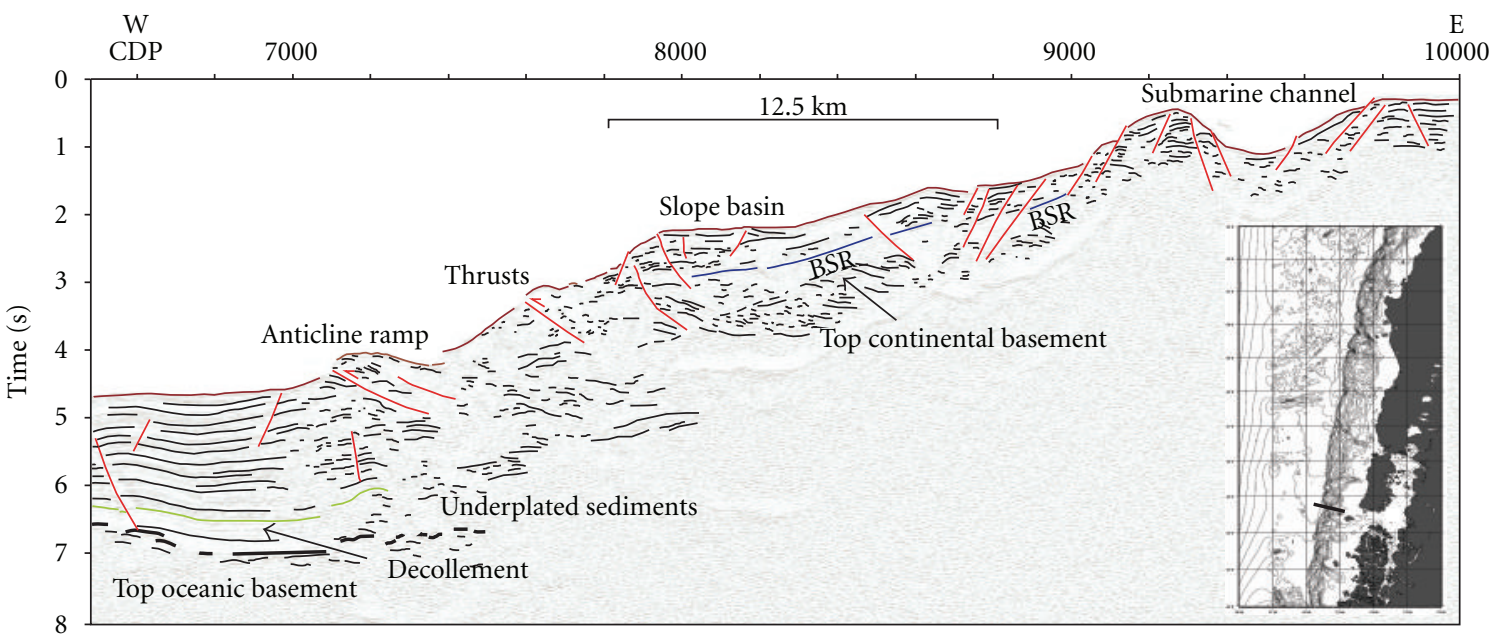

(b)

FIGURE 5: SO161-40 seismic profile. Poststack time-migrated (a) and poststack time-migrated (b) sections with superimposed line drawing section.

while in the SO161-44 and SO161-35 sections (Figure 6(b)) a thicker underplated sediment bed (1.2 s) evidences a steeper and smoother slope. In this way, a greater amount of underplated sediments can determine the formation of duplexes below the accretionary prism affecting accreted sediments and uplifting the internal prism, as evidenced in SO16144, SO161-35, and SO161-29 sections. It seems that the off-scrapped material provides movement accommodations along the thrusts during uplifting generating subhorizontal thrusts. Lateral and vertical growth of accretionary prisms associated to basal accretion has been reported by several authors on different continental margins (i.e, 8, 22, 23, 24 , and 25). On the contrary, in areas where a thinner underplated sediment bed is recognized, the accretionary prism shows thrusts with high offset, which are related to an episodic frontal accretion $[8,12]$. In this case, the underplated material plays a minor role influence. In this way, the evolution for these prisms will be similar to the prisms shown in the previous analyzed sections.
BSRs observed on seismic sections are often considered as indicators of the existence of free gas, delineating the base of the gas hydrate stability zone. Southwards of Juan Fernandez ridge, the BSR was recognized on the internal prism in all sections. In the northernmost part (RC2901-728, SO161-40) and southernmost part (SO161-40 and RC2901-734), the BSR is strong and continuous (Figures 6(a) and 6(b)), while in the central part (SO161-44, SO161-35, and SO161-29) a weak and discontinuous BSR was recognized (Figure 6(b)). So relationships between the BSR characteristics and the accretion processes can be observed; in particular, the BSR is strong and continuous in correspondence with the frontal accretion processes, whereas it is weak and discontinuous in presence of the basal accretion processes. During frontal accretion, tectonic movements seem to affect the frontal prism, but not affecting the internal prism favoring fluid accumulation conditions and consequently formation of strong and continuous BSRs (see right on Figures 6(a) and 6(c)). Meanwhile the uplifting by basal accretion generates 


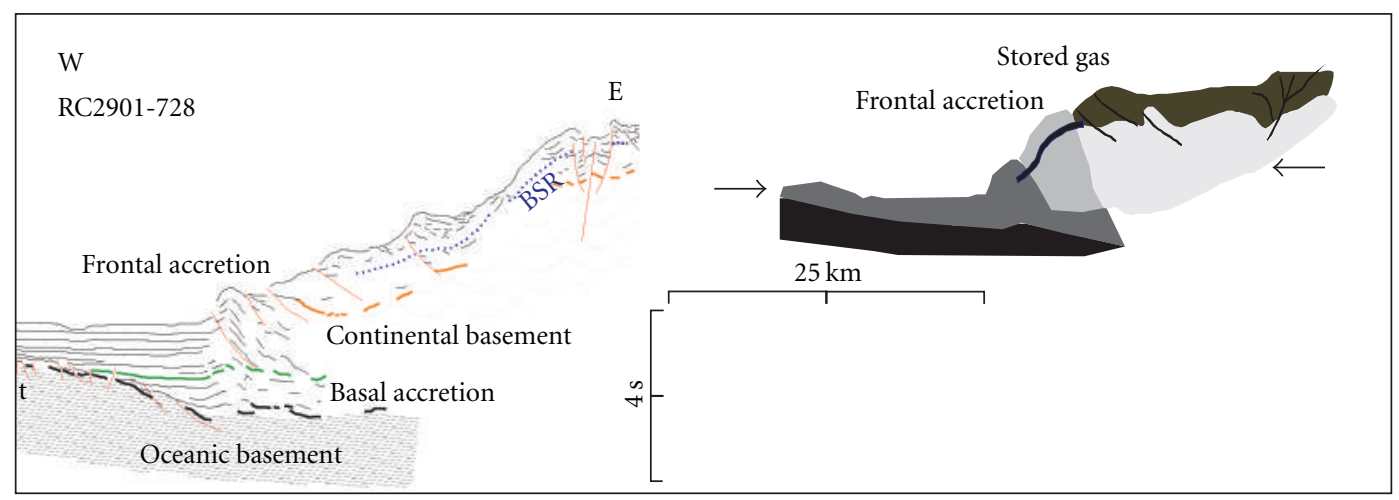

(a)

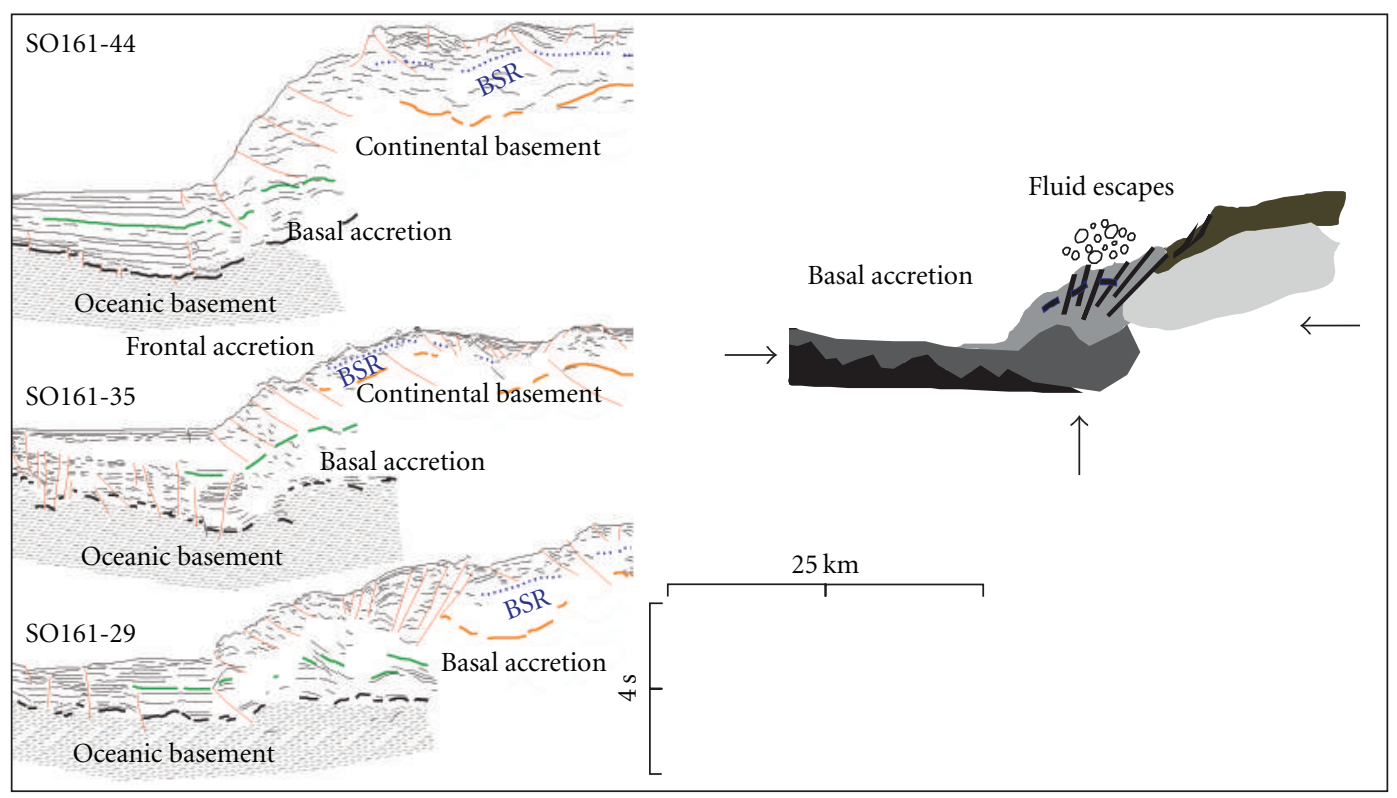

(b)

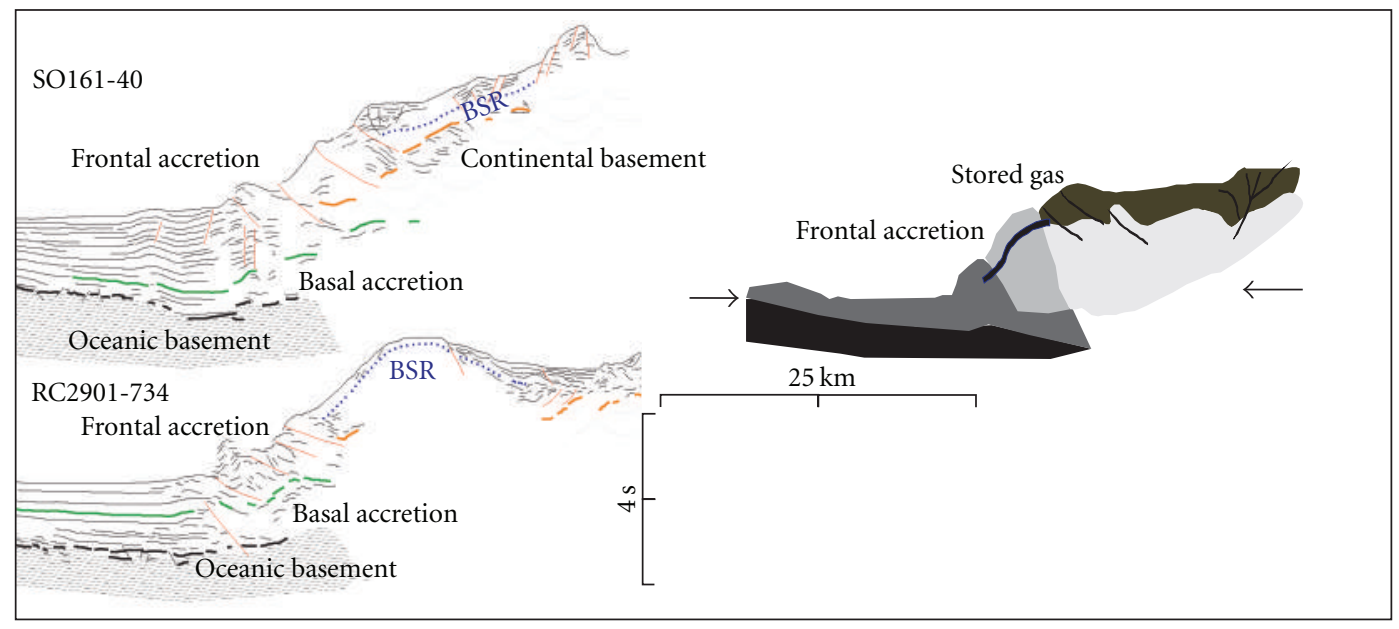

(c)

FIGURE 6: (a) Left: RC2901-728 line drawing profile. Right: frontal accretion diagram. (b) Left: SO161-44, SO161-35, and SO161-29 line drawing profiles. Right: basal accretion diagram. (c) Left: SO161-40 and RC2901-734 line drawing profiles. Right: frontal accretion diagram. 
extensional tectonic movements on the internal prism, which can favour fluid escapes (see right on Figure 6(b)) and, consequently, the change of temperature. So the depth of the gas hydrate stability zone is strongly variable along the seismic line and, consequently, the BSR disappears or becomes weaker. Moreover, a lower geothermal gradient $\left(30^{\circ} \mathrm{C} / \mathrm{km}\right)$ [22] in the northern sector (SO161-44 section) is in agreement with an older oceanic crust (35 Ma) [23], where a reduced fluid circulation can be expected. Whereas, in the southern sector (RC2901-734 section), a higher and variable geothermal gradient $\left(50-95^{\circ} \mathrm{C} / \mathrm{km}\right)[24]$ is in agreement with a younger oceanic crust (15 Ma) [23], where the increased fluid circulation can be expected. Note that the BSR features might be explained considering several factors. Thus, it is possible to associate a weak and discontinuous BSR mainly to a reduced circulation and an active tectonic. However, in the northernmost part (Itata offshore), a strong and continuous BSR is in disagreement with an older oceanic crust. Even if a reduced circulation from oceanic crust is expected, stable tectonic conditions and methane biogenic sources [25] can explain a strongest and continuous BSR in this area. In fact, in Itata offshore from bathymetric data, a smoother continental slope can be recognize, which can be related to steady tectonic regime, while southwards (Arauco and Valdivia offshore) an irregular continental slope characterized by submarine canyons, erosive areas, and structural lineaments can be related to unsteady tectonic regime [26].

\section{Acknowledgments}

The authors are very grateful to Joyce Alsop and Volkmar Damm for seismic data provided by the Lamont Doherty Earth Laboratory (LDEO), USA and the Federal Institute for Geosciences and Natural Resources (BGR), Germany, respectively. This work was partially supported by International Centre for Theoretical Physics (Trieste).

\section{References}

[1] T. H. Shipley, M. H. Houston, R. T. Buffler et al., "Seismic reflection evidence for the widespread occurrence of possible gas hydrate horizons on continental slopes and rises," AAPG Bulletin, vol. 63, pp. 2204-2213, 1979.

[2] R. D. Hyndman and G. D. Spence, "A seismic study of methane hydrate marine bottom simulating reflectors," Journal of Geophysical Research, vol. 97, no. 5, pp. 6683-6698, 1992.

[3] U. Tinivella and F. Accaino, "Compressional velocity structure and Poisson's ratio in marine sediments with gas hydrate and free gas by inversion of reflected and refracted seismic data (South Shetland Islands, Antarctica)," Marine Geology, vol. 164, no. 1-2, pp. 13-27, 2000.

[4] C. Berndt, S. Bünz, T. Clayton, J. Mienert, and M. Saunders, "Seismic character of bottom simulating reflectors: examples from the mid-Norwegian margin," Marine and Petroleum Geology, vol. 21, no. 6, pp. 723-733, 2004.

[5] M. E. Mackay, R. D. Jarrard, G. K. Westbrook, and R. D. Hyndman, "Origin of bottom-simulating reflectors: geophysical evidence from the Cascadia accretionary prism," Geology, vol. 22, no. 5, pp. 459-462, 1994.
[6] N. L. B. Bangs, D. S. Sawyer, and X. Golovchenko, "Free gas at the base of the gas hydrate zone in the vicinity of the Chile triple junction," Geology, vol. 21, no. 10, pp. 905-908, 1993.

[7] K. M. Brown, N. L. Bangs, P. N. Froelich, and K. A. Kvenvolden, "The nature, distribution, and origin of gas hydrate in the Chile Triple Junction region," Earth and Planetary Science Letters, vol. 139, no. 3-4, pp. 471-483, 1996.

[8] J. Diaz-Naveas, Sediment subduction and accretion at the Chilean convergent margin between 35' and 40'S, Dissertation, University of Kiel, Kiel, Germany, 1999.

[9] E. Morales, "Methane hydrates in the Chilean continental margin," Electronic Journal of Biotechnology, vol. 6, no. 2, pp. 3-7, 2003.

[10] I. Grevemeyer, J. L. Diaz-Naveaz, C.R. Ranero, and H. W. Villenger, "Heat Flow over the decensing Nazca plate in Central Chile, $32^{\circ} \mathrm{S}$ to $41^{\circ} \mathrm{S}$ : observations from ODP Leg 202 and the occurrence of natural gas hydrates," Earth and Planetary Sciences Letters, vol. 213, pp. 285-298, 2003.

[11] I. Vargas-Cordero, Gas hydrate occurrence and morphostructures along Chilean margin, Ph.D. thesis, University of Trieste, Trieste, Italy, 2009.

[12] N. L. Bangs and S. C. Cande, "Episodic development of a convergent margin inferred from structures and processes along the southern Chile margin," Tectonics, vol. 16, no. 3, pp. 489-503, 1997.

[13] J. Glodny, H. Echtler, O. Figueroa et al., "Long-term geological evolution and mass-flow balance of the South-Central Andes," in the Andes-Active Subduction Orogeny, O. Oncken, G. Chong, G. Franz et al., Eds., vol. 1 of Frontiers in Earth Science Series, pp. 401-428, Springer, Berlin, Germany, 2006.

[14] C. M. Krawczyk, J. Mechie, S. Lüth et al., "Geophysical signatures and active tectonics at the south-central Chilean margin," in the Andes-Active Subduction Orogeny, O. Oncken, G. Chong, G. Franz et al., Eds., vol. 1 of Frontiers in Earth Science Series, pp. 171-192, Springer, Berlin, Germany, 2006.

[15] D. Angermann, J. Klotz, and C. Reigber, "Space-geodetic estimation of the Nazca-South America Euler vector," Earth and Planetary Science Letters, vol. 171, no. 3, pp. 329-334, 1999.

[16] D. Völker, M. Wiedicke, S. Ladage et al., "Latitudinal variation in sedimentary processes in the Peru-Chile trench off Central Chile," in the Andes-Active Subduction Orogeny, O. Oncken, G. Chong, G. Franz et al., Eds., vol. 1 of Frontiers in Earth Science Series, pp. 193-216, Springer, Berlin, Germany, 2006.

[17] K. Strand, "SEM microstructural analysis of a volcanogenic sediment component in a trench-slope basin of the Chile margin," in Proceedings of the Ocean Drilling Program, Scientific Results, S. D. Lewis, J. H. Behrmann, R. J. Musgrave, and S. C. Cande, Eds., vol. 141, pp. 169-180, 169-180, 1995.

[18] C. Mordojovich, "Sedimentary basins of Chilean Pacific offshore," in Energy Resources of the Pacific Region, M. T. Halbouty, Ed., vol. 12, pp. 63-82, American Association of Petroleum Geologists Studies in Geology, 1981.

[19] K. Rauch, "Cyclicity of Peru-Chile trench sediments between $36^{\circ}$ and $38^{\circ} \mathrm{S}$ : a footprint of paleoclimatic variations?" Geophysical Research Letters, vol. 32, no. 8, pp. 1-4, 2005.

[20] J. K. Cohen and J. W. Stockwell, "CWP/SU: seismic Unix release 35: a free package for seismic research and processing," Center for wave phenomena, Colorado school of Mines, 2001.

[21] O. Yilmaz, Seismic Data Analysis: Processing, Inversion and Interpretation of Seismic Data, Society of Exploration, Tulsa, Okla, USA, 2001.

[22] I. Vargas Cordero, U. Tinivella, F. Accaino, M. F. Loreto, F. Fanucci, and C. Reichert, "Analyses of bottom simulating 
reflections offshore Arauco and Coyhaique (Chile)," GeoMarine Letters, vol. 30, no. 3-4, pp. 271-281, 2010.

[23] R. D. Müller, W. R. Roest, J. Y. Royer, L. M. Gahagan, and J. G. Sclater, "Digital isochrons of the world's ocean floor," Journal of Geophysical Research, vol. 102, no. 2, pp. 3211-3214, 1997.

[24] I. Vargas-Cordero, U. Tinivella, F. Accaino, M. F. Loreto, and F. Fanucci, "Thermal state and concentration of gas hydrate and free gas of Coyhaique, Chilean Margin ( $44^{\circ} 30^{\prime}$ S)," Marine and Petroleum Geology, vol. 27, no. 5, pp. 1148-1156, 2010.

[25] T. Treude, J. Niggemann, J. Kallmeyer et al., "Anaerobic oxidation of methane and sulfate reduction along the Chilean continental margin," Geochimica et Cosmochimica Acta, vol. 69, no. 11, pp. 2767-2779, 2005.

[26] C. Rodrigo, A. González-Fernández, and E. Vera, "Variability of the bottom-simulating reflector (BSR) and its association with tectonic structures in the Chilean margin between Arauco Gulf $\left(37^{\circ} \mathrm{S}\right)$ and Valdivia $\left(40^{\circ} \mathrm{S}\right), "$ Marine Geophysical Researches, vol. 30, no. 1, pp. 1-19, 2009. 

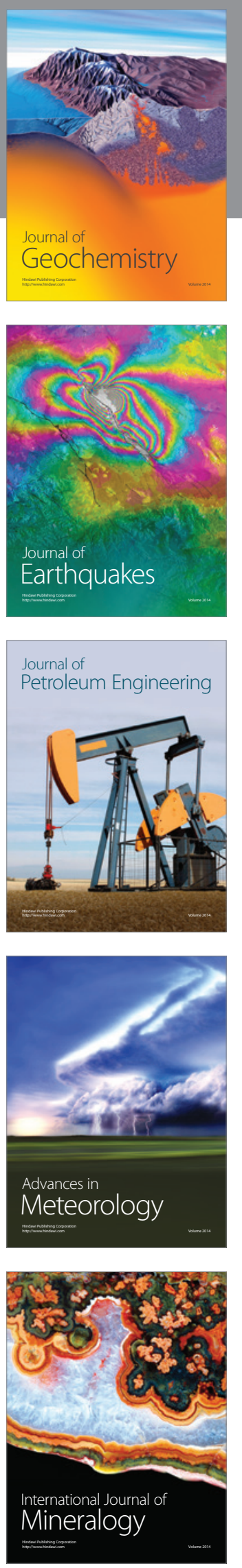
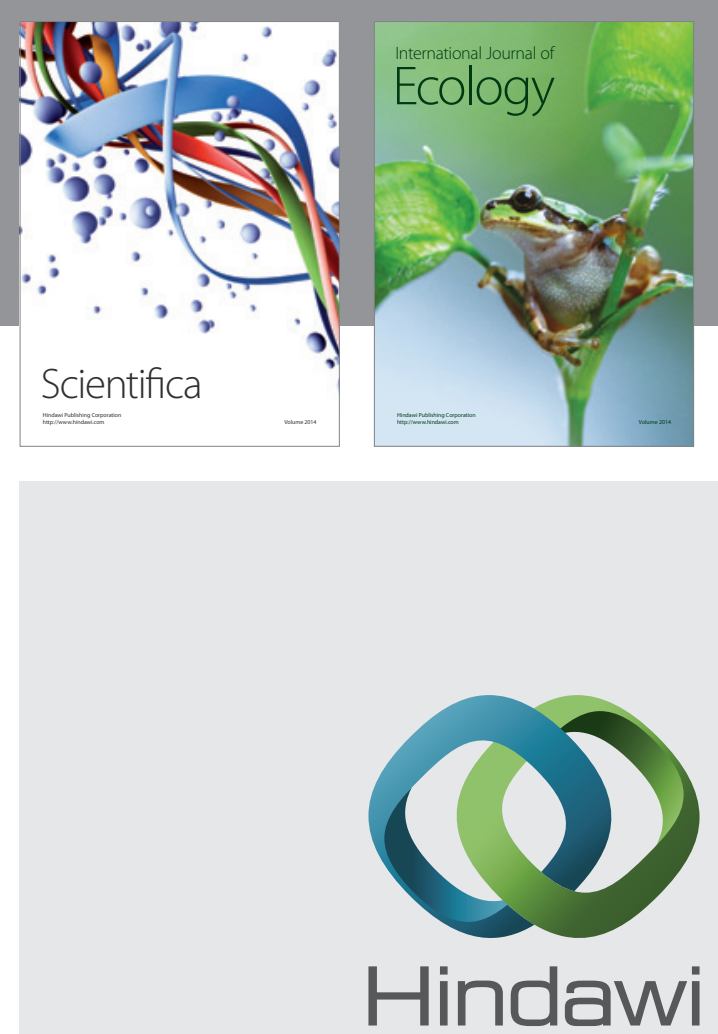

Submit your manuscripts at http://www.hindawi.com
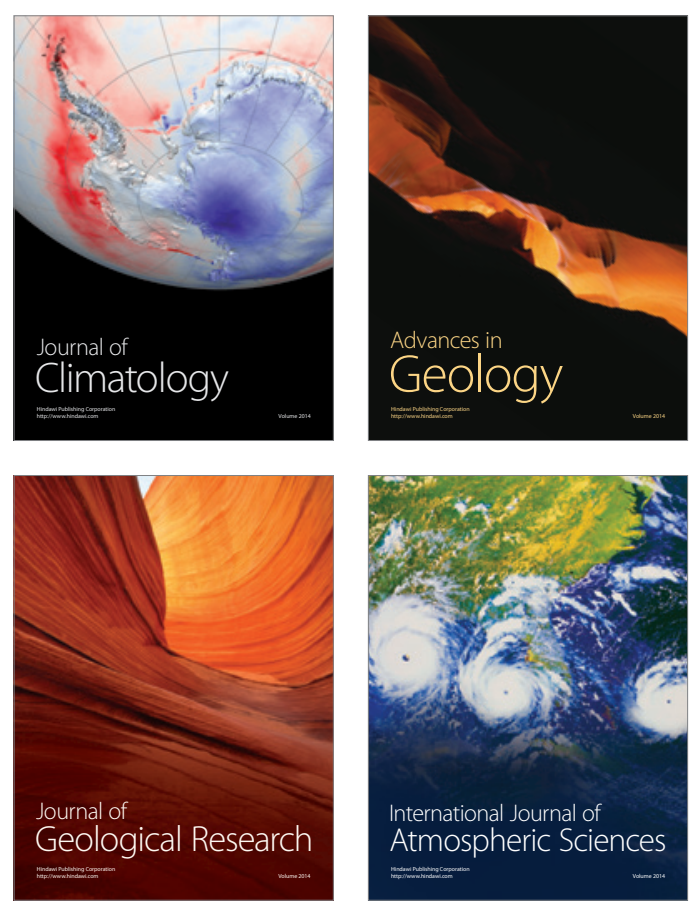
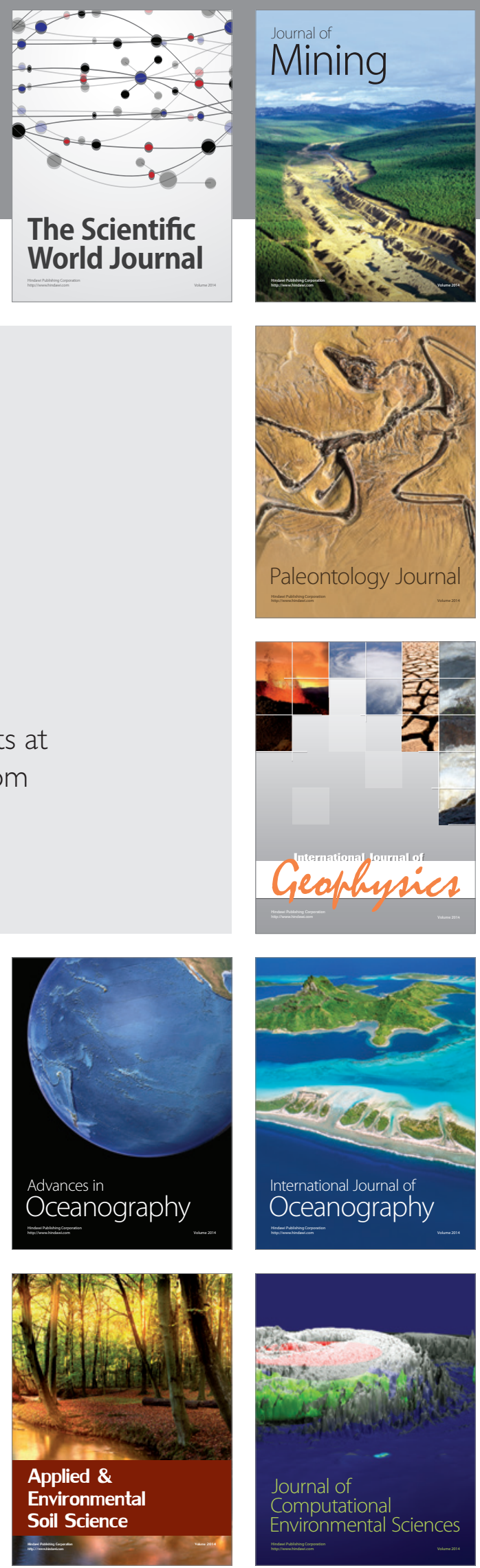